\title{
Pengaruh Bauran Promosi 4C Terhadap Kepuasan Pembelian Online dengan Keputusan Pembelian sebagai Variabel Interverning
}

Imanda Junifar

Sekolah Pascasarjana Universitas Muhammadiyah Prof Dr. Hamka

\begin{tabular}{l}
\hline ARTICLE INFO \\
\hline Article History: \\
Received 26 November 2021 \\
Revised 19 Desember 2021 \\
Accepted 27 Desember 2021 \\
Published 30 Desember 2021
\end{tabular}

\section{Keywords:}

Marketing Mix 4c;

Purchase Decision;

Consumer Satisfaction;

Market Place;

Shopee.

\begin{abstract}
This study aimed to determine the direct and indirect effects of the consumer marketing mix, the price of goods, convenience, and communication contained in the Shopee application. An exploratory quantitative survey method was used in this study. The results show that consumers have a significant effect on purchasing decisions and consumer satisfaction. Price has a significant effect on purchasing decisions and consumer satisfaction. Convenience has a significant effect on consumer satisfaction. However, it has no significant effect on purchasing decisions. Promotion has no effect on consumer satisfaction but has a significant effect on purchasing decisions.
\end{abstract}

\begin{abstract}
Penelitian ini bertujuan untuk mengetahui efek langsung dan tidak langsung dari bauran pemasaran konsumen, harga barang, kenyamanan dan komunikasi yang terdapat dalam aplikasi Shopee. Metode survei kuantitatif eksplorasi yang digunakan dalam penelitian ini. Hasil penelitian menunjukkan bahwa konsumen memiliki efek yang signifikan pada keputusan pembelian dan kepuasan konsumen. Harga memiliki efek signifikan pada keputusan pembelian dan kepuasan konsumen. Kenyamanan memiliki efek signifikan pada kepuasan konsumen. Namun, itu tidak memiliki efek signifikan pada keputusan pembelian. Promosi tidak berpengaruh pada kepuasan konsumen, tetapi memiliki efek signifikan pada keputusan pembelian.
\end{abstract}

\author{
Corresponding Author: \\ Imanda Junifar, \\ Email: imanda05@gmail.ac.id
}

How to Cite: Junifar, Imanda. (2021). Pengaruh bauran promosi 4C terhadap kepuasan pembelian online dengan keputusan pembelian sebagai variabel intervening. Sosio e-Kons, 13 (03), 251-260

\section{PENDAHULUAN}

Perilaku konsumtif dari puluhan juta orang kelas menengah di Indonesia menjadi alasan mengapa e-commerce di Indonesia terus berkembang. Berdasarkan data dari Sirclo.com tahun 2020 pada Q3 tahun lalu, jumlah pengunjung Shopee adalah 55,9 juta orang. Sementara tahun ini, jumlah pengunjungnya mencapai 96,5 juta atau meningkat sekitar $72 \%$. Menurut sirclo.com tahun 2020 marketplace pun juga menjadi platform berbelanja yang paling dipercaya yakni oleh $97 \%$ responden. Sedangkan $91 \%$ percaya untuk berbelanja di website dan $82 \%$ di media sosial. Persaingan ecommerce semakin ketat. Bahkan menurut Bisnis.Tempo.com tahun 2018 persaingan marketplace di Indonesia sangat ketat dan pasar dagang elektronik tidak hanya dikuasai oleh satu pemain dominan. Persaingan e-commerce di Indonesia adalah yang paling ketat di Asia Tenggara. Hal ini dikarenakan Indonesia memiliki pemain lokal yang kuat seperti Tokopedia dan Bukalapak. Jika diurutkan berdasarkan peringkat kunjungan aplikasi terbanyak, marketplace lokal masih masih tetap menduduki posisi teratas, yakni: Shopee, Tokopedia, Bukalapak dan Lazada. Hasil riset MarkPlus, Inc. terkait peta 
kompetisi e-commerce di masa pandemi covid-19 menunjukkan bahwa Shopee menempati urutan pertama sebagai e-commerce yang banyak digunakan selama kuartal III tahun 2020. Shopee menjadi e-commerce dengan top of mind atau paling diingat konsumen dengan $71 \%$, diikuti Tokopedia $15 \%$ Lazada $8 \%$. Kemudian Bukalapak $2 \%$, serta 1\%. JD.id dan Blibli $1 \%$.

Shopee memiliki Bauran Pemasaran/Marketing Mix yang unik. Shopee menggempur habishabisan market indonesia dengan berbagai macam promosi yang bertujuan untuk menjaring sebanyak mungkin pengguna. Promosi yang sangat gencar dilakukan baik internal maupun eksternal aplikasi shopee. Hal ini menghipnotis masyarakat untuk selalu menggunakan shopee untuk berbelanja online. Promosi eksternal yang dilakukan oleh shopee antara lain memanfaatkan berita viral yang ada di sosial media, beriklan diberbagai media baik cetak maupun elektronik, menggunakan artis dan selebgram untuk bahan promosinya, rajin ikut serta dalam event besar skala nasional dan international. Sedangkan promosi internal aplikasi berwujud diskon promosi ongkir yang sangat banyak, hadiahhadiah menarik, dan klaim harga termurah dibandingkan marketplace lainnya.

Dhaneswara (2019) menyatakan bahwa Shopee menggunakan tagline untuk menarik pembeli yang suka berbelanja melalui situs jual beli online. Pada awal kemunculannya sekitar tahun 2015, Shopee menggunakan tagline "Jual Beli di Ponsel". Namun, pada tahun 2016 Shopee mengubah tagline-nya menjadi "Gratis Ongkir Se-Indonesia". Tagline ini berhasil membuat Shopee menjadi banyak dipilih oleh masyarakat sebagai situs jual beli online. Karena pada saat itu belum ada marketplace yang berani mendeklarasikan gratis ongkir kepada penggunanya. Shopee juga berhasil memikat penggunanya dengan claim "Harga Termurah, Jaminan Uang Kembali 2x Lipat". Dengan tagline ini penggunanya benar-benar terbius secara psikologis memilih shopee dibandingkan dengan marketplace lainnya. Harga adalah pertimbangan pertama konsumen ketika membeli sesuatu. Hal inilah yang dimanfaatkan Shopee untuk bersaing dengan platform lain.

Kotler \& Amstrong (2014) menekankan bahwa keputusan pembelian adalah tahap dalam proses pengambilan keputusan pembeli di mana konsumen benar-benar membeli. Sedangkan Schiffman dan Kanuk (2014) menyatakan bahwa keputusan pembelian merupakan keputusan yang diambil dari beberapa alternatif pilihan. Selanjutnya, keputusan pembelian ini akan dipengaruhi oleh faktor internal dan eksternal, sesuai dengan model perilaku konsumen (Hawkins et al, 2007). Sementara itu, Setiadi (2003) menegaskan bahwa konsumen membentuk tujuan pembelian berdasarkan faktor-faktor seperti: pendapatan keluarga yang diharapkan, harga yang diharapkan dan manfaat produk yang diharapkan. Pada saat konsumen ingin bertindak, faktor-faktor keadaan yang tidak terduga mungkin timbul dan merubah tujuan membeli. Buchari (2004) menyimpulkan bahwa keputusan pembelian merupakan suatu keputusan konsumen yang dipengaruhi oleh ekonomi keuangan, teknologi, politik, budaya, kualitas produk, harga, citra merek, lokasi, promosi, physical evidence, people dan process. Pengambilan keputusan pembelian online adalah keputusan yang diambil oleh individu untuk melakukan pembelian terhadap barang atau jasa dengan melalui tahapan pengambilan keputusan. Keputusan ini dipengaruhi oleh faktor internal dan eksternal serta bertujuan untuk menyelesaikan masalah atau memenuhi keinginan dari individu tersebut. Firmansyah (2019) menyatakan bahwa keputusan pembelian merupakan hasil atau keluaran dari hasil kognitif yang membawa kepada suatu tindakan keputusan di antara beberapa alternative yang tersedia. Sementara itu, Koesoemaningsih (2013) menjelaskan bahwa CDP (consumer decision process) adalah tahapan yang dilalui setiap orang untuk memutuskan membeli barang atau tidak. Berikut merupakan tahapan pengembilan keputusan konsumen atau CDP menurut Hawkins et al (2007) antara lain: problem recognition, information search, alternative evaluation and selection, outlet selection and purchase dan postpurchase processes. Blackwell (2006) menyatakan bahwa kepuasan atau satisfaction adalah bertemunya antara harapan dengan hasil yang dirasakan atas sebuah produk, sedangkan ketidak puasan adalah hasil yang dirasakan tidak bisa memenuhi harapan konsumen.

Sumarmi dan Soeprihanto (2010) menjelaskan bahwa marketing mix adalah kombinasi variabel marketing yang merupakan inti dari pemasaran. Sementara itu, Assauri (2013) menambahkan bahwa tidak hanya sebagai variabel dari pemasaran tetapi variabel yang dapat dikendalikan untuk 
mempengaruhi reaksi pembeli atau konsumen. Sedangkan Alma (2016) menekankan bahwa marketing mix adalah strategi bukan alat, yakni strategi sekumpulan kegiatan marketing yang nantinya akan menciptakan kombinasi yang maksimal/paling efektif dalam penjualan. Marketing mix diperkenalkan oleh Jerome McCarthy pada tahun 1960. Pada saat itu Jerome menyatakan bahwa empat variabel marketing mix terdiri dari product, price, place dan promotion yang biasanya dikenal dengan istilah strategi marketing 4P. Namun seiring dengan perkembangan ilmu marketing dan bisnis, konsep ini melebar menjadi 7P. Marketing mix 7p terdiri dari empat elemen strategi marketing 4P dan tiga elemen tambahan yaitu people, process, dan physical evidence (Amera, 2021).

Harga adalah biaya yang dibayar oleh pelanggan untuk mendapatkan produk dan layanan kepada kita. Tidak ada formulasi khsusus untuk hal ini. Yang menjadi patokan harga adalah kesediaan konsumen untuk membayar atas produk tersebut. Artinya perlu ditimbang apakah rela membayar untuk nilai penawaran produk dan layanan kita serta berapa jumlahnya (Octa, 2018). Sedangkan, Sefudin (2014) menyimpulkan bahwa pertimbangan yang harus dilakukan dalam menentukan harga adalah harga yang ditetapkan apakah sesuai dengan bobot solusi yang didapatkan konsumen ketika membeli produk tersebut. Semakin bulat harga yang diberikan tanpa embel-embel lainnya maka akan semakin baik. Selanjutnya, Manafzadeh (2016) menyorot bahwa konsumen akan semakin puas jika konsumen tidak perlu memikirkan biaya lainnya selain harga produk saja. Berdasarkan pengertian dari para ahli tersebut maka pengertian dari harga dalam bauran pemasaran $4 \mathrm{C}$ adalah sejumlah uang yang harus dikorbankan oleh konsumen secara rela untuk memiliki atau mendapatkan suatu produk.

Variabel berikutnya dalam Marketing Mix 4C adalah Convenience/Kenyamanan. Diera digital saat ini semua orang mencari kenyaman dan kemudahan. Kalau bisa, semua harus serba mudah, cepat, singkat, install bahkan tanpa efort yang terlalu berat. Oleh karena itu banyak bisnis yang berlomba-lomba untuk memberikan kenyamanan ini. Sehingga banyak muncul layanan produk yang cepat, simpel, instan, dimana saja, kapan saja untuk menciptakan kenyamanan ini. Ketika kenyamanan ini sudah tercipta maka konsumen akan sulit untuk beralih ketempat lain (Octa, 2018). Perusahaan harus berpikir keras untuk membuat jalur distribusi barang selancar dan senyaman mungkin (Cheng, 2017). Kemudahaan dan kenyamanan dalam mendapatkan produk merupakan faktor yang dipertimbangkan kostumer dalam melakukan suatu transaksi (Timotius dan Vico, 2020).

Komunikasi dalam konsep Marketing Mix 4C adalah Komunikasi aktif dua arah dalam rangka mendeliver nilai lebih/ beda/ keunggulan kepada terget market atau konsumen kita. Promosi pada era digital saat ini sangat lah berbeda dengan era sebelumnya. Komunikasi yang efektif adalah menciptakan hubungan yang lebih bermakna dengan pelanggan dengan fokus kepada kebutuhan dan keinginan pelanggan bukan kepada memaksakan produk yang tidak dibutuhkan oleh pelanggan (Octa, 2018). Paul (2014) menyatakan bahwa perusahaan harus bisa melakukan komunikasi dua arah yang efektif untuk mengetahui keinginan dan kebutuhan dari konsumen. Zimmerrer (2002) menjelaskan bahwa promosi adalah bentuk komunikasi persuasi yang dirancang untuk menginformasikan kepada pelanggan tentang produk atau jasa untuk mempengaruhi mereka agar membeli barang dan jasa tersebut. Saladin (2003) menunjukkan bahwa promosi adalah unsur dalam bauran pemasaran yang bertujuan untuk memberitahu, membujuk, mengingatkan tentang produk perusahaan. Rangkuti (2009) menyimpulkan bahwa promosi adalah cara yang digunakan perusahaan untuk berkomunikasi dengan pasarnya dengan tujuan memberitahu bahwa produk itu ada dan memperkenalkan produk serta memberikan keyakinan akan manfaat produk tersebut kepada pembeli atau calon pembeli. Tjiptono (2015) menganggap bahwa promosi merupakan elemen bauran pemasaran yang berfokus pada upaya menginformasikan, membujuk, dan mengingatkan kembali konsumen akan merek dan produk perusahaan. Dari pengertian tersebut diketahui bahwa promosi adalah kegiatan memperkenalkan produk kepada konsumen, memberikan informasi produk agar konsumen timbul keinginan untuk mencoba dan membali produk tersebut. Promosi juga diharapkan dapat merubah sikap konsumen terhadap produk perusahaan.

Beberapa penelitian terdahulu dapat dijabarkan sebagai berikut: Sudjatmika (2017) menemukan bahwa harga tidak berpengaruh terhadap keputusan pembelian, ulasan produk tidak 
berpengaruh terhadap keputusan pembelian, kemudahan memiliki pengaruh yang positif dan signifikan terhadap keputusan pembelian, keamanan memiliki pengaruh yang positif dan signifikan terhadap keputusan pembelian, kemudahan adalah faktor yang paling berpengaruh terhadap keputusan pembelian dan harga, ulasan produk, kemudahan, dan keamanan secara simultan berpengaruh terhadap keputusan pembelian. Sedangkan Ardyanto dan Riyadi (2015) menyimpulkan bahwa kemudahan memiliki pengaruh yang positif dan signifikan terhadap keputusan pembelian, kepercayaan memiliki pengaruh yang positif dan signifikan terhadap keputusan pembelian dan kemudahan dan kepercayaan secara simultan berpengaruh terhadap keputusan pembelian.

Rumusan masalah yang terdapat dalam penelitian ini adalah: (1) Apakah terdapat pengaruh bauran pemasaran variabel konsumen (costumer) terhadap kepuasan konsumen di aplikasi Shopee? (2) Apakah terdapat pengaruh bauran pemasaran variabel harga barang (cost) terhadap kepuasan konsumen di aplikasi Shopee? (3) Apakah terdapat pengaruh bauran pemasaran variabel kenyamanan (convenience) terhadap kepuasan konsumen di aplikasi Shopee? (4) Apakah terdapat pengaruh bauran pemasaran variabel komunikasi terhadap kepuasan konsumen di Aplikasi Shopee? (5) Apakah terdapat pengaruh tidak langsung bauran pemasaran variabel konsumen (costumer) terhadap kepuasan konsumen melalui keputusan pembelian di aplikasi Shopee? (6) Apakah terdapat pengaruh tidak langsung bauran pemasaran variabel harga produk (cost) terhadap kepuasan konsumen melalui keputusan pembelian di aplikasi Shopee? (7) Apakah terdapat pengaruh tidak langsung bauran pemasaran variabel keyamanan (convenience) terhadap kepuasan konsumen melalui keputusan pembelian di aplikasi Shopee? (8) Apakah terdapat pengaruh tidak langsung bauran pemasaran variabel komunikasi (comunication) terhadap kepuasan konsumen melalui keputusan pembelian di aplikasi Shopee?

Tujuan penelitian ini adalah untuk mengetahui pengaruh langsung dan tidak langsung bauran pemasaran variabel konsumen, harga, kenyamanan, komunikasi terhadap kepuasan konsumen di Marketplace Shopee. Kegunaan praktis dari penelitian ini adalah pebisnis online dapat belajar startegi yang dilakukan Shopee dalam mejaring penggunanya sebanyak mungkin. Sedangkan kegunaan teoritis dari penelitian ini juga dapat berguna untuk semakin menguatkan faktor yang paling signifikan berpengaruh oleh user. Semakin kuat faktor tersebut ada didalam toko online maka semakin besar peluang agar toko tersebut dipilih oleh user.

\section{METODE}

Penelitian ini menggunakan metode survei yang bersifat kuantitatif eksploratori. Bandur (2019) menyatakan bahwa penelitian eksploratif mengeksplorasi bertujuan untuk mengetahui alasan-alasan tertentu terhadap suatu topik atau ingin mengetahui apa yang sedang terjadi pada suatu topik. Untuk tujuan tersebut perlu dilakukan eksplorasi. Sugiyono (2012) menegaskan bahwa penelitian kuantitatif sendiri memiliki pengertian suatu metode penelitian yang berlandaskan pada filsafat positivisme yang digunakan untuk meneliti populasi atau sampel tertentu, pengumpulan data menggunakan instrumen penelitian, analisis data bersifat kuantitatif atau statistik. Data yang digunakan adalah data primer.

Populasi yang digunakan didalam penelitian ini adalah pengguna Apliasi Shopee. Dalam laporan yang dirilis oleh iPrice tahun 2020, Shopee berhasil menggaet pengguna bulanan terbanyak lebih dari 93 juta orang. Namun tidak ada keterangan lebih lanjut mengenai jumlah populasi pengguna Shopee di Kota Bekasi. Dalam penelitian ini sampel yang digunakan adalah pengguna Shopee di Kota Bekasi. Responden harus merupakan konsumen aktif dan suka berbelanja di Shopee sebanyak 200 responden.

Jenis data yang digunakan dalam penelitian ini adalah data primer. Data primer adalah data yang diperoleh dari upaya aktif peneliti untuk mendapatkan data. Data primer biasanya didapatkan dari kegiatan survei, observasi, experiment, kuesioner, wawancara yang tujuannya adalah untuk meperoleh 
data lapangan (Syafnidawaty, 2020). Dalam penelitian ini data primer akan didapatkan melalu kuesioner online berupa Google Form yang akan disebar secara daring.

Tabel 1. Sampel Penelitian

\begin{tabular}{cc} 
& Tabel 1. Sampel Penelitian \\
\hline Banyaknya Variabel & Ukuran Sampel Minimal \\
\hline 3 & 200 \\
5 & 200 \\
10 & 200 \\
15 & 360 \\
20 & 630 \\
25 & 975 \\
30 & 1395 \\
\hline
\end{tabular}

Sumber: Joreskog dan Sorbom (1988)

Dari tabel tersebut dapat diketahui bahwa semakin banyak variabel yang diteliti maka akan semakin banyak jumlah sampel yang diperlukan. Untuk variabel 3-5 dibutuhkan minimal 200 sampel, sedangkan untuk 15 variabel dan diatasnya membutuhkan sampel yang lebih banyak lagi. Dalam penelitian ini menggunakan 5 variabel dalam penelitian, oleh karena itu jumlah sampel yang digunakan adalah 200 sampel. Penelitian ini menggunakan convenience sampling dalam pencarian data. yaitu penulis memilih responden yang mudah ditemui. Penulis memilih responden yang mudah ditemui seperti teman dan saudara Penyebaran dilakukan secara online. Penyebaran dilakukan melalui situs jejaring sosial seperti Facebook, dengan cara penulis mengirim message kepada calon responden untuk mengisi kuesioner beserta attachment link kuesioner. Melalui kuesioner online data lebih mudah untuk didapat karena penulis tidak perlu bertemu langsung dengan responden. Saat menyebar kuesioner secara langsung, penulis meminta izin terlebih dahulu kepada calon responden sebelum memberikan kuesioner dan menjelaskan secara singkat mengenai penelitian yang akan dilakukan. Apabila calon responden bersedia untuk mengisi kuesioner, barulah penulis memberikan kuesioner beserta alat tulis untuk mengisi kuesioner. Responden mengisi kuesioner selama sekitar 10 menit, waktu yang cukup lama karena item yang harus diisi oleh responden cukup banyak yaitu 30 item.

\section{HASIL DAN PEMBAHASAN}

Hasil

Responden dari penelitian ini dapat diketahui pada tabel-tabel berikut di bawah ini yang terdapat pada tabel 2 dan tabel 3.

Tabel 2. Jenis Kelamin Reponden

\begin{tabular}{ccc}
\hline Jenis Kelamin & Jumlah & Persentase \\
\hline Perempuan & 134 & $67 \%$ \\
Laki-laki & 66 & $33 \%$ \\
\hline
\end{tabular}

Berdasarkan hasil observasi, maka dapat diketahui bahwa responden perempuan berjumlah 134 atau $67 \%$. Sedangkan reponden laki-laki berjumlah 66 atau 33\%. Selanjutnya, data yang ditampilkan adalah usia responden.

Tabel 2. Usia Reponden

\begin{tabular}{ccr}
\hline Usia & Jumlah & Persentase \\
\hline$<25$ & 67 & $33,5 \%$ \\
$26-35$ & 72 & $36 \%$ \\
$36-45$ & 43 & $21,5 \%$ \\
$46-55$ & 14 & $7 \%$ \\
$>55$ & 4 & $2 \%$ \\
Total & 200 & $100 \%$ \\
\hline
\end{tabular}


Berdasarkan hasil observasi, maka dapat diketahui bahwa usia responden terbanyak adalah 26-35 sebesar 36\%, disusul usia dibawah 25 tahun yaitu 33,5\% dan usia 36-45 tahun sebesar 21,5\%,.

Tabel 3. Alasan Berbelanja di Shopee

\begin{tabular}{lcr}
\hline \multicolumn{1}{c}{ Alasan } & Jumlah & Persentase \\
\hline Gratis ongkir & 82 & $41 \%$ \\
Produknya berkualitas & 35 & $17.5 \%$ \\
Harga murah & 45 & $22,5 \%$ \\
Banyak diskon menarik & 23 & $11,5 \%$ \\
Karena melihat iklan & 9 & $4,5 \%$ \\
Transaksi aman & 6 & $3 \%$ \\
\hline
\end{tabular}

Berdasarkan hasil observasi, maka dapat diketahui bahwa alasan konsumen berbelanja di Shopee paling banyak adalah gratis ongkir, harga murah dan produknya berkulitas. Selebihnya karena banyak diskon, iklan dan transaksi aman.

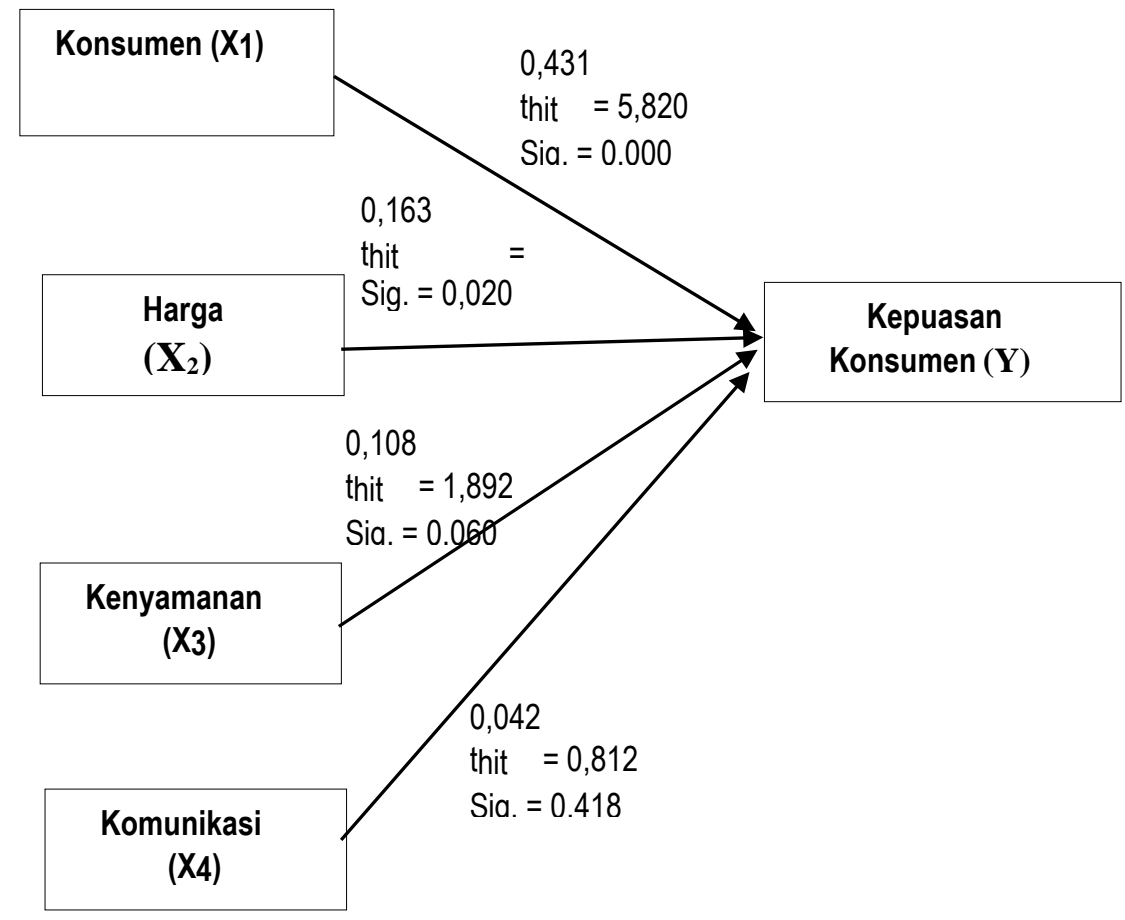

Gambar 1. Analisis Jalur 1

Hasil analisis jalur 1 yang dilakukan oleh peneliti menggunakan aplikasi spss 19, maka didapat pembuktian untuk menguji hipotesis sebagai berikut:

Hipotesis 1: Terdapat Pengaruh Positif Bauran Pemasaran Variabel Konsumen terhadap Kepuasan Konsumen

Berdasarkan bantuan perhitungan dari program SPSS 19, maka terlihat bahwa nilai sig. sebesar 0.000 lebih kecil dari nilai probabilitas 0.05 atau $0.000<0.05$. Sehingga $\mathrm{Ha}$ diterima dan $\mathrm{Ho}$ ditolak. Jika dilihat dari thitung, variabel konsumen (X1) memiliki thitung sebesar 5,820. Kemudian untuk ttabel menggunakan $\mathrm{dk}=\mathrm{n}-2$ dengan adalah jumlah sampel, sehingga hasilnya yaitu $200-2=198$. Sehingga ttabel nya adalah 1,652. Jadi, diperoleh bahwa thitung $>$ ttabel yaitu 5,820 $>1,652$. Sehingga, dapat disimpulkan bahwa variabel konsumen (X1) memiliki pengaruh yang positif dan signifikan terhadap kepuasan konsumen $(\mathrm{Y})$. 


\section{Hipotesis 2: Terdapat Pengaruh Positif Bauran Pemasaran Variabel Harga terhadap Kepuasan Konsumen}

Berdasarkan bantuan perhitungan dari program SPSS 19, maka terlihat bahwa nilai sig. Sebesar 0.020 lebih kecil dari nilai probabilitas 0.05 atau $0.020<0.05$. Sehingga Ha diterima dan $\mathrm{Ho}$ ditolak. Jika dilihat dari thitung, variabel harga $\left(X_{2}\right)$ memiliki thitung sebesar 2,344. Kemudian untuk ttabel menggunakan $d k=n-2$ dengan adalah jumlah sampel, sehingga hasilnya yaitu $200-2=$ 198. Sehingga ttabel nya adalah 1,652. Jadi, diperoleh bahwa thitung $>$ ttabel yaitu 2,344 $>1,652$. Sehingga, dapat disimpulkan bahwa variabel harga (X2) memiliki pengaruh yang positif dan signifikan terhadap kepuasan konsumen $(\mathrm{Y})$.

\section{Hipotesis 3: Terdapat Pengaruh Positif Bauran Pemasaran Variabel Kenyamanan terhadap Kepuasan Konsumen}

Berdasarkan bantuan perhitungan dari program SPSS 19, maka terlihat bahwa nilai sig. sebesar 0.060 lebih besar dari nilai probabilitas 0.05 atau $0.060>0.05$. Sehingga Ha ditolak dan Ho diterima. Jika dilihat dari thitung, variabel kenyamanan (X3) memiliki thitung sebesar 1,892. Kemudian untuk ttabel menggunakan $\mathrm{dk}=\mathrm{n}-2$ dengan adalah jumlah sampel, sehingga hasilnya yaitu $200-2=$ 198. Sehingga ttabel nya adalah 1,652. Jadi, diperoleh bahwa thitung $>$ ttabel yaitu 1,892 $>1,652$. Sehingga, dapat disimpulkan bahwa variabel kenyamanan (X3) memiliki pengaruh yang positif namun tidak signifikan terhadap kepuasan konsumen $(Y)$.

Hipotesis 4: Terdapat Pengaruh Positif Bauran Pemasaran Variabel Komunikasi terhadap Kepuasan Konsumen

Berdasarkan bantuan perhitungan dari program SPSS 19, maka terlihat bahwa nilai sig. sebesar 0.418 lebih besar dari nilai probabilitas 0.05 atau $0.418>0.05$. Sehingga Ha ditolak dan Ho diterima. Jika dilihat dari thitung, variabel komunikasi (X4) memiliki thitung sebesar 0,812. Kemudian untuk ttabel menggunakan $\mathrm{dk}=\mathrm{n}-2$ dengan adalah jumlah sampel, sehingga hasilnya yaitu $200-2=$ 198. Sehingga ttabel nya adalah 1,652. Jadi, diperoleh bahwa thitung < ttabel yaitu 0,812<1,652. Sehingga, dapat disimpulkan bahwa variabel komunikasi (X4) tidak memiliki pengaruh yang positif terhadap kepuasan konsumen $(Y)$.

Untuk mengetahui apakah variabel keputusan pembelian mampu memediasi variabel baruan promosi 4C yang terdiri dari konsumen, harga produk, kenyamanan, dan komunikasi terhadap kepuasan konsumen, adapun langkahnya sebagai berikut:

Hipotesis 5: Terdapat Pengaruh Tidak Langsung Bauran Pemasaran Variabel Konsumen terhadap Kepuasan Konsumen Melalui Keputusan Pembelian (Analisis Pengaruh $\mathrm{X}_{1}$ melalui Z Terhadap Y)

Diketahui pengaruh langsung yang diberikan $X 1$ terhadap $Y$ sebesar 0,431 . Sedangkan pengaruh tidak langsung $X 1$ melalui $Z$ terhadap $Y$ adalah perkalian antara nilai beta $X 1$ terhadap $Z$ dengan nilai beta $Z$ terhadap $Y$, yaitu: $0,182 \times 0,475=0,086$. Maka pengaruh total yang diberikan $X 1$ terhadap $Y$ adalah pengaruh langsung ditambah pengaruh tidak langsung yaitu $0,431+0,086=0,517$. Berdasarkan perhitungan tersebut diketahui bahwa nilai pengaruh langsung lebih besar dari pengaruh tidak langsung. Hal ini dapat diartikan bahwa secara tidak langsung, konsumen melalui keputusan pembelian terhadap kepuasan konsumen berpengaruh secara tidak signifikan.

Hipotesis 6: Terdapat Pengaruh Tidak Langsung Bauran Pemasaran Variabel Harga terhadap Kepuasan Konsumen Melalui Keputusan Pembelian (Analisis Pengaruh $\mathrm{X}_{2}$ melaluiZ Terhadap Y)

Diketahui pengaruh langsung yang diberikan $X 2$ terhadap $Y$ sebesar 0,163 . Sedangkan pengaruh tidak langsung $X 2$ melalui $Z$ terhadap $Y$ adalah perkalian antara nilai beta $X 2$ terhadap $Z$ dengan nilai beta $Z$ terhadap $Y$, yaitu: $0,244 \times 0,475=0,116$. Maka pengaruh total yang diberikan $X 2$ terhadap $Y$ adalah pengaruh langsung ditambah pengaruh tidak langsung yaitu $0,163+0,116=0,279$. Berdasarkan perhitungan tersebut diketahui bahwa nilai pengaruh langsung lebih besar dari pengaruh tidak langsung. Hal ini dapat diartikan bahwa secara tidak langsung, pengaruh harga produk melalui keputusan pembelian terhadap kepuasan konsumen berpengaruh secara tidak signifikan. 


\section{Hipotesis 7: Terdapat Pengaruh Tidak Langsung Bauran Pemasaran Variabel Kenyamanan terhadap Kepuasan Konsumen Melalui Keputusan Pembelian(Analisis Pengaruh $\mathrm{X}_{3}$ melalui $Z$ Terhadap Y)}

Diketahui pengaruh langsung yang diberikan $X 3$ terhadap $Y$ sebesar 0,108 . Sedangkan pengaruh tidak langsung $X 3$ melalui $Z$ terhadap $Y$ adalah perkalian antara nilai beta $X 3$ terhadapZ dengan nilai beta $Z$ terhadap $Y$, yaitu: $0,045 \times 0,475=0,021$. Maka pengaruh total yang diberikan $X 2$ terhadap $Y$ adalah pengaruh langsung ditambah pengaruh tidak langsung yaitu $0,108+0,021=0,129$. Berdasarkan perhitungan tersebut diketahui bahwa nilai pengaruh langsung lebih besar dari pengaruh tidak langsung. Hal ini dapat diartikan bahwa secara tidak langsung, pengaruh kenyamanan melalui keputusan pembelian terhadap kepuasan konsumen berpengaruh secara tidak signifikan

Hipotesis 8: Terdapat Pengaruh Tidak Langsung Bauran Pemasaran Variabel Komunikasi terhadap Kepuasan Konsumen Melalui Keputusan Pembelian (Analisis Pengaruh $\mathrm{X}_{4}$ melalui Z Terhadap Y)

Diketahui pengaruh langsung yang diberikan $X 4$ terhadap $Y$ sebesar 0,042 . Sedangkan pengaruh tidak langsung $X 4$ melalui $Z$ terhadap $Y$ adalah perkalian antara nilai beta $X 4$ terhadap $Z$ dengan nilai beta $Z$ terhadap $Y$, yaitu: $0,131 \times 0,475=0,062$. Maka pengaruh total yang diberikan $X 4$ terhadap $Y$ adalah pengaruh langsung ditambah pengaruh tidak langsung yaitu $0,042+0,062=0,104$. Berdasarkan perhitungan tersebut diketahui bahwa nilai pengaruh tidak langsung lebih besar dari pengaruh langsung. Hal ini dapat diartikan bahwa secara tidak langsung, pengaruh komunikasi melalui keputusan pembelian terhadap kepuasan konsumen berpengaruh secara signifikan.

\section{SIMPULAN DAN SARAN}

Berdasarkan hasil penelitian dan pembahasan yang telah diuraikan sebelumnya dapat diambil kesimpulan bahwa: Didalam penelitian ini terdapat pengaruh bauran pemasaran variabel produk terhadap kepuasan konsumen pengguna aplikasi Shopee di Kota Bekasi. Hasil ini diperoleh dari nilai thitung variabel produk sebesar 5,820 sedangkan nilai ttabel 1,652, maka thitung $>$ ttabel. Hal ini membuktikan bahwa variabel produk mempengaruhi variabel kepuasan konsumen. Artinya apabila produk semakin baik maka tingkat kepuasan konsumennya juga semakin baik. Begitupun sebaliknya jika produk kurang baik, maka akan mempengaruhi tingkat kepuasan konsumennya menjadi semakin menurun. Variabel produk juga yang memiliki pengaruh paling tinggi terhadap kepuasan konsumen dibandingkan dengan variabel yang lain dilihat dari nilai koefisiennya yaitu 0,454 .

Dalam penelitian ini terdapat pengaruh bauran pemasaran variabel harga produk terhadap kepuasan konsumen pengguna aplikasi Shopee di Kota Bekasi. Hasil ini diperoleh dari nilai thitung variabel harga produk sebesar 2,344 sedangkan nilai ttabel 1,652, maka thitung > tabel. Hal ini membuktikan bahwa variabel harga produk mempengaruhi variabel kepuasan konsumen. Artinya apabila harga produknya semakin baik maka tingkat kepuasan konsumennya juga semakin baik. Begitupun sebaliknya jika harga produknya kurang baik, maka akan mempengaruhi tingkat kepuasan konsumennya yang akan menjadi semakin menurun.

Dalam penelitian ini terdapat pengaruh bauran pemasaran variabel convenience terhadap kepuasan konsumen pengguna aplikasi Shopee di Kota Bekasi namun tidak signifikan. Hasil ini diperoleh dari nilai thitung variabel kenyamanan sebesar 1,892 sedangkan nilai ttabel 1,652, maka thitung > tabel. Namun, jika dilihat dari nilai signifikansinya yaitu 0,060 atau $>0,05$. Sehingga dinyatakan berpengaruh positif namun tidak signifikan. Hal ini membuktikan bahwa variabel kenyamanan mempengaruhi variabel kepuasan konsumen secara tidak signifikan atau pengaruhnya bisa dikatakan kecil.

Tidak terdapat pengaruh bauran pemasaran variabel komunikasi terhadap kepuasan konsumen. Hasil ini diperoleh dari nilai thitung variabel komunikasi sebesar 0,812 sedangkan nilai tabel 
1,652, maka thitung < tabel. Hal ini membuktikan bahwa variabel kemonikasi tidak mempengaruhi variabel keputusan pembelian.

Terdapat pengaruh tidak langsung bauran pemasaran variabel produk melalui keputusan pembelian terhadap kepuasan konsumen aplikasi Shopee di Kota Bekasi. Namun, besaran koefisiennya tidak menunjukkan pengaruh yang signifikan karena koefisien nilai pengaruh langsung dari variabel produk terhadap kepuasan konsumen lebih besar dari nilai pengaruh tidak langsungnya melaui keputusan pembelian yaitu sebesar 0,238. Sehingga dapat disimpulkan bahwa koefisien keputusan pembelian dapat memediasi variabel produk terhadap kepuasan konsumen walaupun tidak signifikan dibandingkan dengan variabel lain.

Terdapat pengaruh tidak langsung bauran pemasaran variabel harga produk melalui keputusan pembelian terhadap kepuasan konsumen aplikasi Shopee di Kota Bekasi. Hal ini diketahui dari nilai pengaruh langsung variabel harga produk terhadap kepuasan konsumen lebih kecil dari nilai pengaruh tidak langsungnya. Sehingga dapat disimpulkan bahwa koefisien mediasi 0,330 yang berarti bahwa keputusan pembelian mampu memediasi harga produk terhadap kepuasan konsumen.

Terdapat pengaruh tidak langsung bauran pemasaran variabel convenience melalui keputusan pembelian terhadap kepuasan konsumen aplikasi Shopee di Kota Bekasi. Namun, besaran koefisiennya tidak menunjukkan pengaruh yang signifikan karena koefisien nilai pengaruh langsung dari variabel convenience terhadap kepuasan konsumen lebih besar dari nilai pengaruh tidak langsungnya melaui keputusan pembelian yaitu sebesar 0,065. Sehingga dapat disimpulkan bahwa koefisien keputusan pembelian dapat memediasi variabel convenience terhadap kepuasan konsumen walaupun tidak signifikan dibandingkan dengan variabel lainnya.

Terdapat pengaruh tidak langsung komunikasi melalui keputusan pembelian terhadap kepuasan konsumen aplikasi Shopee di Kota Bekasi. Hal ini diketahui dari nilai pengaruh langsung variabel komunikasi terhadap kepuasan konsumen lebih kecil dari nilai pengaruh tidak langsungnya. Sehingga dapat disimpulkan bahwa koefisien mediasi 0,208 yang berarti bahwa keputusan pembelian mampu memediasi komunikasi terhadap kepuasan konsumen.

\section{REFERENCES/DAFTAR PUSTAKA}

Ardiansyah, putra. Pengaruh strategi bauran pemasaran terhadap kepuasan dan loyalitas pelanggan giant hypermarket di surabaya. Diss. Stie perbanas surabaya, 2015.

Alwafi, fachrizi, and rizal hari magnadi. "pengaruh persepsi keamanan, kemudahan bertransaksi, kepercayaan terhadap toko dan pengalaman berbelanja terhadap minat beli secara online pada situs jual beli tokopedia. Com." diponegoro journal of management 5.2 (2016): 134-148.

Arli, Denni, Fandy Tjiptono, and Rebecca Porto. "The impact of moral equity, relativism and attitude on individuals' digital piracy behaviour in a developing country." Marketing Intelligence \& Planning (2015).

Awamleh, Raed, and Cedwyn Fernandes. "Internet Banking: An empirical investigation into the extent of adoption by banks and the determinants of customer satisfaction in the United Arab Emirates." (2005): 1.

Bandur, Agustinus. "School-based management developments: challenges and impacts." Journal of educational administration (2012).

Blakwell, R., D’Souza, C., Taghian, M., Miniard, P. and Engel, J, (2006). Consumer Behaviour: An Asia Pasific Approach, Australia: Thomson Learning.

Bruner II, Gordon C., and Anand Kumar. "Explaining consumer acceptance of handheld Internet devices." Journal of business research 58.5 (2005): 553-558.

Bruner, I. I., and C. Gordon. "Marketing scales handbook." (2012).

Buchari, Alma. "Manajemen Pemasaran Perusahaan Jasa." (2013). 
Cheng, Jui-Hung, and Shuo-Fang Liu. "A study of innovative product marketing strategies for technological SMEs." Journal of Interdisciplinary Mathematics 20.1 (2017): 319-337.

DHANESWARA, VANI ANINDYA. "Pengaruh Tagline "Gratis Ongkir" Shopee Terhadap Keputusan Berbelanja Online Pada Masyarakat (Studi Pada Masyarakat Kota Bandar Lampung)." (2019).

Ercho, Mohammad Renaldo, et al. "Pengaruh citra celebrity endorser pada brand image terhadap purchase decision: studi kasus endorser Ariel." (2013).

Firmansyah, m. Anang, and mm se. Perilaku konsumen (sikap dan pemasaran). Penerbit qiara media, 2019.

Fukey, Mudita Sinha Dr Leena N. "Web user Experience and Consumer behaviour: The Influence of Colour, Usability and Aesthetics on the Consumer Buying behaviour." STUDIES 2000 (2005): 5.

Furuhashi, Y. Hugh, and E. Jerome McCarthy. "Social issues of marketing in the American economy." Marketing and the Common Good. Routledge, 2013. 117-126.

Haryono, novan, and roony octavia. "analisis pengaruh citra merek dan mutu layanan terhadap kepuasan konsumen serta dampaknya terhadap loyalitas konsumen." jurnal industri elektro dan penerbangan $4.2(2020)$.

Hawkins, D.I, Mothersbaugh, D.L, Best, R.J, (2007). Consumer Behavior: Building Marketing Strategy 10th edition. New York: Mc Graw Hill Irwin.

Herdiana, Erik. Pengaruh Advertising (Peringatan Bahaya Rokok) Produk Rokok Djarum MLD Terhadap Persepsi Konsumen Di Kabupaten Sumedang. Diss. STIE Ekuitas, 2017.

https://distribusipemasaran.com/bauran-pemasaran-yang-fokus-ke-pelanggan/, Agus Octa, 2018

https://Sirclo.com/

https://www.kominfo.go.id/

Kotler, P. and Keller, K.L, (2009). Marketing Management. 13th edition, New Jersey: Pearson Education.

Kotler, Philip. Kotler on marketing. Simon and Schuster, 2012.

Kusnendi, M. S. "Model-model Persamaan Struktural Satu dan Multigroup Sample dengan LISREL." Alfabeta, Bandung (2008).

Oliver, Richard. L, (2010). Satisfaction: A Behavioral Perspective on the Consumer. New York: M.E. Sharpe, Inc.

Paul, Tarak. "Customer communication dimension of marketing mix-a review of gap between mutual fund investors' expectation and experience." Scholars Journal of Economics, Business and Management 1.5 (2014): 197-202.

Sofjan, Assauri. "Manajemen Bisnis Pemasaran." (2018).

Sugiyono, F. X. Neraca pembayaran: Konsep, Metodologi dan penerapan. Vol. 4. Pusat Pendidikan dan Studi Kebanksentralan (PPSK) Bank Indonesia, 2017. 